
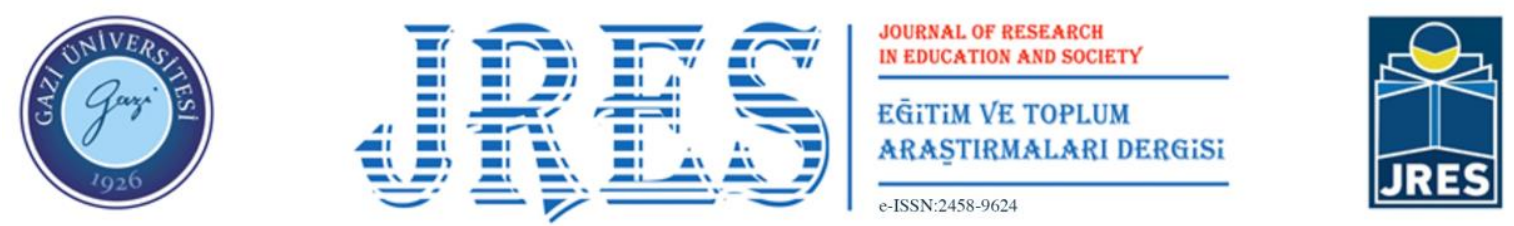

Cilt: 8 Sayı: 1 Sayfa Aralığı: 167-178 e-ISSN:2458-9624 DOI: 10.51725/etad.906161

\title{
Okul Öncesi Öğretmen Adaylarının Meslek Tercih Nedenleri: İçsel ve Dişsal Faktörler
}

\author{
Career Choice Reasons of Pre-School Teacher Candidates: \\ Instrinsic and Extrinsic Factors
}

\section{Aycan Buldur, Meryem Ezgi Keskin, Esma Börekçi}

\section{ÖZ}

Öğretmen adaylarının öğretmenlik mesleğini tercih etme nedenleri, mesleki performansları ve gelecek beklentileri üzerinde etkili olması nedeniyle önem taşımaktadır. Bu bağlamda bu araştırmanın amacı da okul öncesi öğretmen adaylarının öğretmenlik mesleğini tercih etme nedenlerini incelemektir. Araştırmanın çalışma grubunu bir devlet üniversitesinin Okul Öncesi Öğretmenliği Anabilim dalında öğrenim görmekte olan 90 öğretmen adayı oluşturmaktadır. Görüşme formu aracılığıyla toplanan veriler kategorisel içerik analizi yöntemiyle analiz edilmiştir. Analizler sonucunda öğretmen adaylarının öğretmenlik mesleğini hem içsel hem de dişsal faktörlerle tercih ettikleri ortaya çıkmıştır. Ancak tercih nedenlerinde içsel faktörlerin dişsal faktörlere kıyasla daha etkili olduğu tespit edilmiştir. Diğer taraftan elde edilen bulgulara göre katılımcıların büyük bir kısmı üniversiteye yerleşme aşamasında okudukları bölümü ilk sıralarda tercih ettiklerini ve tekrar tercih şansları olsa okul öncesi öğretmenliği programını yeniden tercih edeceklerini ifade etmişlerdir.

Yazar Bilgileri
Aycan Buldur (D
Dr. Öğr. Üyesi, Sivas
Cumhuriyet Üniversitesi,
Sivas, Türkiye
aycanbuyuktanir@gmail.com
Meryem Ezgi Keskin (iD
Öğretmen, Sivas Cumhuriyet
Üniversitesi, Sivas, Türkiye
ezgi keskin58@gmail.com
Esma Börekçi (iD
Öğretmen, Sivas Cumhuriyet
Üniversitesi, Sivas, Türkiye
brkcesma2@gmail.com

Makale Bilgileri

Anahtar Kelimeler

Okul öncesi eğitim

Öğretmen adayı

Meslek seçim nedenleri

Keywords

Preschool education

Teacher candidate

Career choice reasons

Makale Geçmişi

Geliş: 30/03/2021

Düzeltme: $21 / 05 / 2021$

Kabul: 26/05/2021

Atıf için: Buldur, A., Keskin, M.E. ve Börekçi, E. (2021). Okul öncesi öğretmen adaylarının meslek tercih nedenleri: İçsel ve dişsal faktörler. JRES, 8(1), 167-178. https://doi.org/10.51725/etad.906161 


\section{Giriş}

Okul öncesi eğitimin çocukların gelişimindeki rolü büyüktür. Çünkü bu dönem çocukların tüm gelişim alanlarının desteklendiği ve kişiliğinin oluşmaya başladığı dönemdir (Haktanır, Dağlıŏlu ve Güler, 2010). Nitelikli okul öncesi eğitimi alan çocukların okul başarıları olumlu yönde gelişmektedir ve okul yaşamına uyum düzeyi artmaktadır (Ada, Küçükali, Akan ve Dal, 2014; Carnes ve Albrecht, 2007; Sak ve Tezel-Şahin, 2007; Santoro, 2011). Çocukların okula uyum düzeylerinin artmasında ve okula yönelik olumlu tutum geliştirmelerinde okul öncesi öğretmenleri en önemli faktörlerden biridir. Öğretmenlerin duygu, düşünce ve davranışları bu süreçte çocukların üzerinde büyük bir rol oynamaktadır. Çünkü eğitim ortamları ne kadar donanımlı olursa olsun, öğretmenin mesleki bilgi, beceri ve kişilik özellikleri eğitimin temel belirleyicisidir (Yalçın, Yalçın ve Macun, 2017). Bu bağlamda öğretmenlerin en önemli kişilik özelliklerinden biri de öğretmen olmaya ilişkin motivasyonlarıdır. Çünkü öğretmenlerin mesleki performanlarının en önemli bileşenlerinden biri öğretmenlik mesleğini tercih etme nedenleridir (Bruinsma ve Jansen, 2010). Meslek tercihi özelde öğretmenler genelde ise tüm meslekler için önemli bir faktördür. Kişi ilgisi ve yeteneği doğrultusunda kendini mutlu edeceği mesleği seçmelidir. Bu yüzden meslek seçimi insan hayatında önemli bir yer tutmaktadır (Çelikten, Şanal ve Yeni, 2005). Öğretmenler, toplumun kültür ve değerlerinin genç kuşaklara kazandırılmasında ve nitelikli insan gücünün yetiştirilmesinde en önemli etkendir. Öğretmenlerin içinde bulunduğu bu önemli konumdan dolayı, öğretmen adaylarının mesleklerini neden tercih ettiklerinin incelenmesi önemlidir (Çelikten, Şanal ve Yeni, 2005).

Öğretmenlik mesleğini tercih etme nedenleri ile ilgili yapılan bazı araştırmalarda öğretmenlik mesleğinin ilk sıralarda tercih edilen mesleklerden biri olmadığ 1 ve öğretmen adaylarının öğretmenliği ideallerindeki meslek olarak görmedikleri ortaya konmuştur (Anılan ve Anılan, 2014; Bursal ve Buldur, 2013; Şahin, 2011). Bu istenmedik sonuçlar oldukça önemlidir zira, öğretmenlik mesleğini gönüllü olarak seçmiş olanların diğerlerine göre tutumları daha olumludur (Aslan ve Köksal-Akyol, 2006; Buldur ve Bursal, 2015; Eret-Orhan ve Ok, 2014; Şahin, 2011) ve öğretmenlerin mesleği tercih etme nedenleri onların verimliliklerini etkilemektedir (Bruinsma ve Jansen, 2010).

Öğretmenlik mesleğini tercih nedenleriyle ilgili araştırmalar incelendiğinde, öğretmenlik mesleğini tercih etme sebeplerinin birçok faktöre bağlı olduğu belirlenmiştir (Brookhart ve Freeman, 1992). Alanyazında genel olarak öğretmen adaylarının mesleklerini tercih etme sebepleri özgecilik (çocukların geleceğine katkıda bulunma, topluma hizmet vb.), içsel (çalışacağı yaş grubundaki çocukları çok sevme, idealindeki meslek olması vb.) ve dişsal (çalışma saatleri ve tatiller vb.) faktörler olmak üzere üç grupta incelenmektedir (Bastick, 2000; Bruinsma ve Jansen, 2010; Saban, 2003; Yu ve Bieger, 2013).

Ulusal alanyazında öğretmen adaylarının meslek tercih nedenleri ile ilgili olarak birçok çalışma yapılmıştır. Bursal ve Buldur (2013) çalışmalarında öğretmen adaylarının meslek tercih nedenlerini ve bu nedenlerin etki derecelerini belirlemek amacıyla "Öğretmenlik Tercih Nedenleri Derecelendirme" ölçeğini geliştirmiş̧ir. Yine aynı araştırmacılar farklı bir çalışmada (Buldur ve Bursal, 2015) fen bilgisi öğretmen adaylarının mesleki geleceklerine yönelik beklenti düzeyleri ile meslek tercih nedenleri incelemişlerdir. Araştırma sonucunda fen bilgisi öğretmen adaylarının meslek tercih nedenlerinde, özgeci, içsel ve dışsal faktörlerin etkili olduğunu ve katılımcıların gelecek beklentilerinin genellikle olumlu olduğu belirlenmiştir. Benzer bir diğer araştırmada Boz ve Boz (2008) ise kimya ve matematik öğretmen adaylarının öğretmenliği tercih etme nedenlerini incelemişler ve meslek tercih nedenlerinde dışsal nedenlerin baskın geldiğini tespit etmişlerdir. Yine matematik öğretmen adayları ile yürütülen bir diğer çalışmada Hacıömeroğlu ve Şahin-Taşkın (2009) katılımcıların; öğretmeyi sevme, iş olanağı, 
çalışma saatlerinin uygunluğu gibi nedenlerden dolayı öğretmenlik mesleğini tercih ettiklerini belirlemişlerdir.

Alanyazında yürütülen bazı çalışmalarda ise öğretmen adaylarının meslek tercih nedeni faktörlerinin etki dereceleri kıyaslanmıştır. Bu çalışmalardan birinde Saban (2003) meslek tercihinde özgeci ve dışsal etkenlerin içsel etkenlerden daha baskın olduğunu belirtirken; Özbek, Kahyaoğlu ve Özgen (2007) içsel faktörlerin, dışsal faktörlere kıyasla daha baskın olduğunu tespit etmiştir. Özsoy, Özsoy, Özkara ve Memiş (2010) çalışmalarında 855 öğretmen adayınının meslek tercihinde etkili olan faktörleri incelemişler ve en yaygın olan tercih nedeninin özgeci faktörler olduğunu belirlemişlerdir. Bursal ve Buldur (2016) çalışmalarında altı farklı ana bilim dalındaki öğretmen adaylarının mesleki geleceklerine yönelik beklentileri ve öğretmenlik mesleği tercihlerinde özgeci, içsel ve dışsal faktörlerin etki düzeylerini araştırmışlardır. Araştırma sonucunda öğretmen adaylarının çoğunun mesleki geleceklerine yönelik beklentilerinin olumlu olduğunu ve öğretmenlik mesleği tercihlerinde sırasıyla özgeci, içsel ve dışsal faktörlerin etkili olduğunu tespit etmişlerdir.

$\mathrm{Bu}$ konuda yapılan bazı araştırmalarda ise öğretmenlik meslek tercih nedenleri ile farklı değişkenler arasındaki ilişkiler konu edinmiştir. Bu çalışmalardan birinde Nalçacı ve Sökmen (2016) sınıf öğretmeni adaylarıyla yürüttükleri çalışmalarında öğretmen adaylarının meslek tercih nedenlerinin öğretmenlik mesleğine yönelik tutumlarını etkilediği sonucuna varmışlardır. Bir diğer araştırmada ise Erdiller-Yatmaz, Erdemir ve Erbil (2019) çalışmalarında okul öncesi öğretmenliği adaylarının meslek seçiminde rol oynayan faktörlerin ne olduğunu ve bunların öğretmen adaylarının çocuk ve çocukluğa dair algılarıyla ne yönlerden benzediğini araştırmışlardır. Araştırma sonucunda öğretmen adaylarının meslek tercihlerinde en önemli faktörün içsel motivasyonları olduğunu tespit etmişlerdir. Farklı bir araştırmada Kılcan, Keçe, Çepni ve Kılınç (2014), öğretmen adaylarının meslek tercih nedenlerini araştırdıkları çalışmaları sonucunda meslek tercih nedenlerinin öğrenim görülen anabilim dalına göre farklılaştığı sonucuna ulaşmışlardır.

Öğretmen adaylarının meslektercih nedenlerine ilişkin olarak yapılan araştırmaların çoğunda farklı anabilim dalları aynı örneklem grubu içinde incelenmiştir ve tek anabilim dalına yönelik yapılan çalışmaların (Beşoluk ve Horzum, 2011; Boz ve Boz, 2008; Bozdoğan, Aydın ve Yıldırım, 2007; Buldur ve Bursal, 2015; Bursal ve Buldur, 2013; Çetin, 2012; Çevik ve Yiğit, 2009; Hacıömeroğlu ve Şahin-Taşkın, 2009; Öztürk-Akar, 2012; Şahin, 2011) az sayıda olduğu göze çarpmaktadır. Bu nedenle, tek bir anabilim dalındaki öğretmen adayları ile araştırmaların yapılması önem taşımaktadır. Bu önemden hareketle bu araştırmanın örneklemini sadece okul öncesi öğretmen adayları oluşturmuştur. Bu çalışmada, Okul Öncesi Öğretmenliği Anabilim dalında öğrenim gören öğretmen adaylarının öğretmenlik mesleğini tercih etme nedenleri ortaya konmuştur.

\section{Araştırmanın Amacı ve Önemi}

Bireylerin okul öncesi öğretmenlik mesleğini tercih etmesinde, çocukları sevmesi ve onlara ilgi göstermesinin dışında öğretmenin mesleki yeterlikleri ve kişisel özellikleri önemlidir (Downing, Ryndak ve Clark, 2000; Eskicumalı, 2002). Öğretmenlerin mesleki yeterlikleri üzerine yapılan araştırmalarda, meslek seçiminin gönüllü olarak yapılmadığ duygusuna daha çabuk kapıldıkları belirlenmiştir (Kuruüzüm ve Çelik, 2005; Telef, 2011; Yazıcı, 2009). Öğretmen adaylarının öğretmenlik mesleğine yönelik inanç ve tutumları öğretmenlerin kalitesini belirleyen etkenlerden biridir (Brookhart ve Freeman, 1992; Çakıroğlu ve Çakıroğlu, 2003). Çünkü öğretmen adaylarının öğretmenlik mesleğini seçme nedenleri ilerideki meslek hayatlarındaki performanslarını etkilemektedir (Bursal ve Buldur 2016). Bu açıdan bakıldığında çocukların da 
öğretmenlerinin meslek tercihlerinden doğrudan ya da dolaylı olarak etkilendikleri söylenebilir (Thomson, Turner ve Nietfeld, 2011). Bundan dolayı öğretmenlik mesleğinin tercih edilme nedenlerini derinlemesine incelemek gerekmektedir. Bireylerin öğretmenlik mesleğini tercih etmesinde iş bulma olasılığı, gelecek garantisi, mesleğe toplumdaki olumlu bakış açısı gibi çeşitli nedenler etkili olmaktadır (Balyer ve Özcan, 2014; Mtika ve Gates, 2011; Richardson ve Watt, 2005; Rots, Aelterman, Devos ve Vlerick, 2010; Sinclair, 2008; Tomšik, 2016). Geleceğin öğretmenleri olan öğretmen adaylarının meslek seçiminde etkili olan faktörler gelecek nesillerimizin eğitimi için önemli olacağından bu çalışmada, okul öncesi öğretmen adaylarının neden bu mesleği seçtiklerine ilişkin görüşlerini ortaya koymak amacıyla yürütülmüştür.

Bu amaç doğrultusunda aşağıdaki alt problemlere yanıt aranmıştır.

1. Okul öncesi öğretmen adaylarının mesleklerini tercih etme sebepleri nelerdir?

2. Okul öncesi öğretmen adaylarının öğrenim gördükleri programı tercih etme sıraları nasıldır?

3. Okul öncesi öğretmen adaylarının üniversiteye yeniden başlama fırsatları olması durumunda mesleği tekrar tercih etmeye ilişkin görüşleri nasıldır?

\section{Yöntem}

\section{Araştırma Modeli}

$\mathrm{Bu}$ çalışma nitel araştırma desenlerinden durum çalışması deseninde gerçekleştirilmiştir. Çalışmada durum çalışması deseninin esas alınma nedeni bu tür çalışmalarda bir olayı ya da olguyu oluşturan ayrıntıların tanımlanması, buna ilişkin açıklamaların geliştirilmesi ve değerlendirilmesidir (Büyüköztürk, Kılıç-Çakmak, Akgün, Karadeniz ve Demirel, 2008).

\section{Çalışma Grubu}

$\mathrm{Bu}$ araştırmanın çalışma grubunu bir devlet üniversitesinin Okul Öncesi Öğretmenliği Anabilim dalında öğrenim gören 90 öğretmen adayı oluşturmaktadır. Çalışma grubunun belirlemesinde kolay ulaşılabilir örnekleme tekniği esas alınmıştır. Katılımcıların cinsiyet, mezun oldukları lise türü ve sınıf düzeylerine ilişkin dağılımlarına ait bilgiler Tablo 1, 2 ve 3'te yer almaktadır.

Tablo 1. Katılımcıların Cinsiyete Göre Dağılımı

\begin{tabular}{lccc}
\hline & Kiz & Erkek & Toplam \\
\hline Frekans & 71 & 19 & 90 \\
Yüzde & 78,8 & 21,1 & 100 \\
\hline
\end{tabular}

Tablo 2. Katılımcıların Mezun Oldukları Okul Türlerine Göre Dağılımları

\begin{tabular}{lcccccc}
\hline & $\begin{array}{c}\text { Anadolu } \\
\text { Lisesi }\end{array}$ & $\begin{array}{c}\text { Fen } \\
\text { Lisesi }\end{array}$ & $\begin{array}{c}\text { Kiz Meslek } \\
\text { Lisesi }\end{array}$ & Genel Lise & Diğer & Toplam \\
\hline $\begin{array}{l}\text { Frekans } \\
\text { Yüzde }\end{array}$ & 59 & 3 & 9 & 18 & 1 & 90 \\
\hline
\end{tabular}

Tablo 3. Katılımcıların Sınıf Düzeylerine Göre Dağılımları

\begin{tabular}{lcccc}
\hline & 2.Sınıf & 3. Sınıf & 4.Sınıf & Toplam \\
\hline Frekans & 42 & 44 & 4 & 90 \\
Yüzde & 46,7 & 48,9 & 4,4 & 100,0 \\
\hline
\end{tabular}


Tablo 1 incelendiğinde araştırmaya katılan öğretmen adaylarının büyük bir kısmının kız (\% $78,8)$ olduğu görülmektedir. Tablo 2'ye göre ise mezun olunan okul türü değişkeni dikkate alındığında katılımcılarının yarıdan fazlasının Anadolu Lisesi (\% 65,5) mezunu oldukları göze çarpmaktadır. Katılımcıların sınıf düzeyi dikkate alındığında da çalışmaya ağırlıklı olarak 2 ve 3. sınıf öğrencilerinin katıldığı görülmektedir.

\section{Etik Bildirim}

$\mathrm{Bu}$ araştırma, 01.01.2020 tarihinden önce yapıldı̆̆ından etik kurul kararı zorunluluğu yoktur. Yapılan bu araştırmada bilimsel, etik ve alıntı kurallarına uyulmuştur.

\section{Veri Toplama Araçları}

Veriler, araştırmacılar tarafından hazırlanan görüşme formu aracılığıyla toplanmıştır. Araştırmacılar tarafından alanyazın ışı̆̆ında hazırlanan taslak form alan uzmanlarının görüşlerine sunulmuş ve görüşler doğrultusunda forma son hâli verilmiştir. İki bölümden oluşan görüşme formunun birinci bölümünde çalışma grubuna ait demografik bilgilere ilişkin sorular yer alırken ikinci bölümünde ise araştırma alt problemlerine ilişkin üç soruya yer verilmiştir.

\section{Verilerin Toplanması}

Veriler, 2019-2020 öğretim yılı güz dönemi sonunda toplanmıştır. Çalışmanın geçerliliğinin yüksek olması amacıyla katılımcılar araştırmanın amacı hakkında bilgilendirilmiş ve çalışmaya katılımda gönüllü olan katılımcıların görüşme formlarını doldurmaları sağlanmıştır.

\section{Verilerin Analizi}

Araştırmada toplanan veriler kategorisel içerik analizi yöntemiyle analiz edilmiştir. İçerik analizi toplanan verileri açıklayabilecek kavramlara ve ilişkilere ulaşma ya da sözel ve yazılı materyallerin kapsadığı mesaj ve anlamları nesnel ya da sistematik olarak sınıflandırma ve çıkarımda bulunma işidir (Yıldırım ve Şimşek, 2013). Kategorisel içerik analiz sürecinde; (i) verilerin kodlanması, (ii) temaların [kategorilerin] oluşturulması, (iii) temaların düzenlenmesi (vi) bulguların tanımlanması aşamaları izlenmiştir. Veri analizinin güvenirliğinin artırılmasının sağlanması amacıyla analiz süreci detaylı olarak betimlenmiş ve doğrudan alıntılardan yararlanılmıştır.

\section{Bulgular}

\section{Birinci Alt Probleme İlişkin Bulgular}

Araştırmada ele alınan birinci alt problem “Okul öncesi öğretmen adaylarının meslek tercih sebepleri nelerdir?" şeklinde ifade edilmiştir. Katılımcıların bu araştırma problemi doğrultusunda verdikleri cevaplar analiz edilerek elde edilen bulgular Tablo 4 'te sunulmuştur.

Tablo 4. Öğretmen Adaylarının Okul Öncesi Öğretmenliğini Tercih Etme Sebepleri

\begin{tabular}{rcrr}
\hline & Tercih Sebepleri & $f$ & \% \\
\hline & İdeal mesleği olması & 15 & 14,32 \\
\cline { 2 - 5 } & Kişiliğe ve karaktere uygun olması & 12 & 10,00 \\
\cline { 2 - 5 } & Çocuklarla iletişimin güçlü olması & 12 & 14,32 \\
\cline { 2 - 5 } & Çocukluk hayali olması & 9 & 16,66 \\
\cline { 2 - 5 } & Öğretmeyi ve çocukları sevme & 8 & 8,88 \\
\hline \multirow{2}{*}{} & Toplam & 56 & 62,22 \\
\hline
\end{tabular}




\begin{tabular}{|c|c|c|c|}
\hline \multirow{8}{*}{ 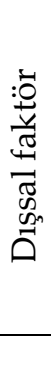 } & Rahat ve kolay bir meslek olması & 8 & 8,88 \\
\hline & İş bulma ve atama garantisi olması & 7 & 7,77 \\
\hline & Çevrenin etkisi & 7 & 7,77 \\
\hline & Ailenin isteği & 4 & 4,44 \\
\hline & Kadınlara uygun meslek olması & 3 & 3,33 \\
\hline & Üniversite yerleştirme puanının yetmesi & 2 & 2,22 \\
\hline & Mesai ve çalışma saatlerinin az olması & 2 & 2,22 \\
\hline & Toplam & 33 & 36,66 \\
\hline
\end{tabular}

Tablo 4’e bakıldığında öğretmen adaylarının öğretmenlik mesleğini tercih etme sebeplerinin iki ana kategoride toplandığı görülmektedir. Bu kategoriler "İçsel Faktörler" ve "Dişsal faktörler" olarak adlandırılmıştır. Meslek tercih nedenleri ile ilgili frekanslara bakıldığında ise meslek tercih nedenlerinde içsel faktörlerin dışşal faktörlere kıyasla daha ağırlıkta olduğu söylebilir.

Katılımcıların meslek tercih nedenlerinde en etkili faktörün öğretmenliğin “ideal mesleği olması" olduğu göze çarpmaktadır. Bunu sırasıyla "kişiliğe ve karaktere uygun olması" ile "çocuklarla iletişimin güçlü olması" faktörleri takip etmiştir. Bazı öğretmen adayları ise öğretmenlik mesleğinin çocukluk hayalleri olması ve çocuklarla olan iletişimlerinin güçlü olması nedenleriyle bu mesleği tercih ettiklerini ifade etmişlerdir. İçsel faktörler kategorisi ile ilgili olarak katılımcıların örnek ifadeleri aşağıda yer almaktadır:

"Çocuklarla iyi bir bağ kurduğum için seçtim. Çocukları çok seviyorum." (Ö60)

"Kendi karakterime en uygun meslek olduğunu düşünüyorum." (Ö59)

"Kendi kişiliğime uygun olduğunu düşünüyorum."(Ö65)

"Çocukluk hayalimdi ve bu yüzden liseden sonra bu bölümü seçtim." (Ö49)

"Kendi yeteneklerim ve ilgilerim doğrultusunda yapabileceğim bir meslek. Kendi kişiliğime uygun bir meslek". (Ö19)

Tablo 4 incelendiğinde bazı öğretmen adaylarının ise öğretmenlik mesleğini dışsal faktörlerin etkisiyle tercih ettikleri görülmektedir. Dışsal faktörler arasında frekansı en yüksek sebebin ise öğretmenlik mesleğinin rahat ve kolay bir meslek olması olduğu göze çarpmaktadır. Diğer taraftan meslekte iş bulma garantisi olması ve çevrenin etkisinin de dışsal faktörler arasında yüksek frekansa sahip oldukları görülmektedir. Katılımcılardan bazıları ise meslek tercihlerinde "Ailenin isteği", "Kadınlara uygun meslek olması", Üniversite yerleştirme puanının yetmesi" ve "Mesai ve çalışma saatlerinin az olması" gibi nedenlerin etkili olduğunu belirtmişlerdir. Katılımcıların dışsal faktörler kategorisi ile ilgili örnek ifadeleri aşağıda yer almaktadır:

"Ailemin ssrarn ile tercih ettim." (Ö1)

“Öğretmenim etkili oldu bu mesleği seçerken..."(Ö61)

“Bu bölümü istemeyerek ama sonradan çocuklarn tatlılı̆̆ı ve masumiyetini görünce isteyerek okuyorum. Tarih okumak istiyordum. Fakat Türkiye'de istediğin bölümü okumama gibi bir sıkıntı var." (Ö72)

"Ataması iyi olduğu için tercih ettim." (Ö31)

“"Puanım bu bölüme yettiği için YKS sonuçlarına göre bu bölümü tercih ettim." (Ö48)

"Çalışma saatleri az ve tatilleri çok olduğu için bayanlara özel bir meslek olduğu için seçtim. " (Ö30) 


\section{İkinci Alt Probleme İlişkin Bulgular}

Araştırmada ele alınan ikinci alt problem "Okul öncesi öğretmen adaylarının öğrenim gördükleri programı tercih etme sıraları nasıldır?" şeklinde ifade edilmiştir. Katılımcıların bu araştırma problemi doğrultusunda verdikleri cevaplar analiz edilerek elde edilen bulgular Tablo 5'te sunulmuştur.

Tablo 5. Öğretmen Adaylarının Okul Öncesi Öğretmenliğini Tercih Etme Sırası

\begin{tabular}{lcccccc}
\hline & $\begin{array}{c}\text { Ilk } \\
\text { Tercihler }\end{array}$ & $\begin{array}{c}\text { Son } \\
\text { Tercihler }\end{array}$ & $\begin{array}{c}\text { Yatay } \\
\text { Geçiş }\end{array}$ & Hatırlamiyorum & $\begin{array}{c}\text { Geçersiz } \\
\text { Cevap }\end{array}$ & Toplam \\
\hline Frekans & 70 & 15 & 1 & 1 & 3 & 90 \\
Yüzde & 77,7 & 16,6 & 1,1 & 1,1 & 3,3 & 100,0 \\
\hline
\end{tabular}

Tablo 7 incelendiğinde öğretmen adaylarının büyük çoğunluğu $(\% 77,7)$ üniversiteye yerleşme aşamasındaki bölüm tercih sürecinde okul öncesi öğretmenliğini ilk sıralarda seçtiklerini az bir kısmı ise $(\%$ 16,6) son sıralarda bu bölümü tercih ettiklerini ifade etmişlerdir. Görüldüğü gibi öğretmen adaylarının çoğunluğu okudukları bölümü ilk sıralarda tercih etmişlerdir.

\section{Üçüncü Alt Probleme İlişkin Bulgular}

Araştırmada ele alınan üçüncü alt problem "Okul öncesi öğretmen adaylarının üniversiteye yeniden başlama firsatları olması durumunda mesleği tekrar tercih etmeye ilişkin görü̈sleri nasıldır?" şeklinde ifade edilmiştir. Katılımcıların bu araştırma problemi doğrultusunda verdikleri cevaplar analiz edilerek elde edilen bulgular Tablo 6'da sunulmuştur.

Tablo 6. Okul Öncesi Öğretmen Adaylarının Üniversiteye Yeniden Başlama Fırsatları Olması Durumunda Mesleği Tekrar Tercih Etmeye İlişkin Görüşleri

\begin{tabular}{lcccc}
\hline & $\begin{array}{c}\text { Yeniden } \\
\text { Tercih etme }\end{array}$ & $\begin{array}{c}\text { Yeniden } \\
\text { Tercih etmeme }\end{array}$ & Kararsiz & Toplam \\
\hline Frekans & 68 & 21 & 1 & 90 \\
Yüzde & 75,5 & 21,3 & 1,1 & 100,0 \\
\hline
\end{tabular}

Tablo 8 incelendiğinde öğretmen adaylarının büyük bir kısmının $(\% 75,5)$ üniversiteye yeniden başlama fırsatları olması durumunda okudukları bölümü tekrar tercih etmeyi düşündükleri göze çarpmaktadır. Bunun yanı sıra katılımcıların yaklaşık olarak beşte biri ise yeniden tercih şansları olsa bu bölümü seçmeyeceklerini belirtmişlerdir.

\section{Tartışma, Sonuç ve Öneriler}

Bu çalışma okul öncesi öğretmen adaylarının öğretmenlik mesleğini tercih etme nedenlerini araştırmak amacıyla yapılmıştır. Çalışma kapsamında öğretmen adaylarına görüşme formu aracılığıyla sorular yöneltilmiştir. Araştırmada toplanan veriler kategorisel içerik analizi yöntemiyle analiz edilmiştir.

Elde edilen bulgular ışığında öğretmen adaylarının okul öncesi öğretmenlik mesleğini tercih etme sebeplerine bakıldığında, katılımcıların öğretmenlik mesleğini hem içsel hem de dışsal faktörlerle tercih ettikleri görülmektedir. Bu sonuç öğretmenlik meslek tercihlerinin tek boyutlu değil de çok boyutlu olmasının (Brookhart ve Freeman, 1992; Sinclair, 2008) bir yansıması olarak değerlendirilebilir. Bulgular daha detaylı incelendiğinde katılımcıların meslek tercihlerinde içsel faktörlerin dışsal faktörlere kıyasla daha baskın olduğu göze çarpmaktadır. Birinci alt problem kapsamında ulaşılan bu bulgu ikinci ve üçüncü alt problemlerde elde edilen bulgularla da uyumludur. Çünkü ikinci alt probleme göre katılımcılar üniversite bölüm tercih aşamasında okudukları bölümü ilk sıralarda tercih 
ettiklerini vurgulamışlardır. Benzer olarak üçüncü alt problem kapsamında ise katılımcıların büyük bir kısmı tekrar tercih şansları olsa okul öncesi öğretmenliği anabilimdalını yeniden tercih edeceklerini ifade etmişlerdir. Bu bulgular katılımcıların içsel faktörlerle mesleği tercih etmeleri bulgusuyla paralellik taşımaktadır. Bu sonuca paralel olarak okul öncesi öğretmen adayları ile yürütülen farklı bir araştırma da Erdiller-Yatmaz vd. (2019) çalışmaları sonucunda okul öncesi öğretmen adaylarının meslek tercihlerinde en önemli faktörün içsel motivasyonları olduğunu tespit etmişlerdir. Yine benzer sonuçlara ulaşılan ve Türkiye'de öğretmenlik meslek tercih nedenleri ile ilgili yapılan ve 51 farklı eğitim fakültesinden 18226 öğretmen adayı ile yürütülen çok kapsamlı bir çalışmada Aksu, Engin-Demir, Daloglu, Yıldırım ve Kiraz (2010) katılımcıların \%51'inin öğretmenlik mesleği tercihinde en önemli etken olarak öğretmen olma isteğinin geldiğini tespit etmişlerdir. Yine aynı çalışmada katılımcıların meslek tercihlerinde en önemli ikinci faktörün ise üniversite yerleştirme puanı olduğu sonucuna ulaşılmıştır. Yapılan bu çalışmada da öğretmen adaylarının bir kısmı meslek tercih nedenlerinde üniversite yerleştirme puanlarının etkili olduğunu ifade etmişlerdir.

Araştırmada ulaşılan ilgi çekici bir sonuç ise öğretmen adaylarının önemli bir kısmının öğretmenlik mesleğini dışsal faktörlerle tercih etmeleridir. Bu sonuç Türkiye'de yapılan ve öğretmen adaylarının dışsal faktörlerin etkisiyle öğretmenlik mesleğini tercih ettiklerinin tespit edildiği bazı (Çetin, 2012; Ekiz, 2006; Hacıömeroğlu ve Şahin-Taşkın, 2009; Ok ve Önkol, 2007) araştırma sonuçlarıyla uyumludur.

Araştırmada ulaşılan ilginç bir sonuç ise katılımcıların meslek tercih nedenlerinde özgeci faktörlere yer vermemiş olmalarıdır. Bu sonuç Türkiye'deki öğretmen adaylarının meslek tercih nedenleri ile ilgili yürütülen bazı araştırmalarda (Buldur ve Bursal, 2015; Bursal ve Buldur, 2013; Öztürk-Akar, 2012; Özsoy vd., 2010; Saban, 2003) ulaşılan özgeci faktörlerin öğretmenlik mesleğini tercih etmekte en etkili faktör olması sonucu ile paralellik göstermemektedir. Bu farklılığın olası bir nedeninin çalışmaların yürütüldüğü branşlarla ilgili olduğu söylenebilir. Çünkü farklı öğretmenlik branşlarında öğretmen adaylarının üniversite yerleştirme puanları ve atanma oranlarının büyük oranda farklılıklar göstermektedir. Branş farklılıklarından kaynaklanan bu tür farklılıkların öğretmen adaylarının meslek tercih nedenleri üzerinde önemli bir etkiye sahip olması göz ardı edilemez (Buldur ve Bursal, 2015).

Sonuç olarak bu araştırmada okul öncesi öğretmen adaylarının meslek tercihlerinde içsel faktörlerin baskın olmakla birlikte dışsal faktörlerinde etkili olduğu tespit edilmiştir. Öğretmen adaylarının meslek tercihlerinde içsel faktörlerin baskın olması olumlu olmakla birlikte dışsal faktörlerinde önemli bir etkiye sahip olması düşündürücüdür. Çünkü öğretmen adaylarının dışsal nedenlerle meslek seçimi yapması mezun olduklarında verecekleri okul öncesi eğitimin kalitesi açısından önemli sorunlara yol açabilir. Çünkü birçok araştırmada (Bozdoğan vd., 2007; Watt ve Richardson, 2008) öğretmenliği içsel nedenlerle tercih edenlerin mesleğe yönelik tutumlarının diğerlerine kıyasla daha olumlu olduğu vurgulanmıştır. Öğretmenlerin mesleğe yönelik tutumlarının onlarında performanslarını etkileyeceği gerçeğinden de hareketle, bu sorunların önlenebilmesi adına öğretmenlik programlarına öğrenci seçiminde içsel motivasyona sahip öğrencilerin tercih edileceği düzenlemeler yapılabilir.

Öğretmen adaylarının öğretmenlik mesleğine yönelik tercihleri onların aldıkları eğitimi, gelecekteki mesleki hayatlarının kalitesini ve öğrencilerinin başarısını etkilemektedir (Atav ve Altunoğlu, 2013). Bu açıdan bu konuda yapılacak çalışmaların sayısının artırılması önerilmektedir. Ayrıca, öğretmen adaylarının meslek tercih nedenleri lisans eğitimi aldıkları anabilim dalına göre 
farklılık gösterebileceği gerçeğinden hareketle benzer araştırmaların farklı anabilim dalları ile yürütülmesi de önerilmektedir.

\section{Kaynaklar}

Ada, Ş., Küçükali, R., Akan, D. ve Dal, M. (2014). Okul öncesi eğitim kurumlarında yönetim sorunları. Middle Eastern \& African Journal of Educational Research (MAJER), 12, 32-59.

Aksu, M., Engin-Demir, C., Daloglu, A., Yıldırım, S. ve Kiraz, E. (2010). Who are future teachers in Turkey? Characteristics of entering student teachers. International Journal of Educational Development, 30(1), 91-101.

Anılan, B. ve Anılan, H. (2014). Fen bilgisi öğretmen adaylarının fen bilgisi öğretmenliğini seçme nedenleri ve gelecek beklentileri. Ĕ̆gitim ve Öğretim Araştırmaları Dergisi, 3(3), 51-64.

Aslan, D. ve Köksal-Akyol A. (2006). Okul öncesi öğretmen adaylarının mesleğine yönelik tutumları ve mesleki benlik saygılarının incelenmesi. Ç.Ü. Sosyal Bilimler Enstitüsü Dergisi, 15(2), 51-60.

Atav, E. ve Altunoğlu, B.D. (2013). Meslek ve alan seçiminde motivasyon ölçeğinin Türkçe formunun geçerlik ve güvenirlik çalışması. Hacettepe Üniversitesi Ĕ̆itim Fakültesi Dergisi, 28(2), 58-70.

Balyer, A. ve Özcan, K. (2014). Choosing teaching profession as a career: Students' reasons. International Education Studies, 7(5), 104-115.

Bastick, T. (2000). Why teacher trainees choose the teaching profession: Comparing trainees in metropolitan and developing countries. International Review of Education, 46(3/4), 343-349.

Beşoluk, Ş. ve Horzum, M.B. (2011). Öğretmen adaylarının meslek bilgisi, alan bilgisi dersleri ve öğretmen olma isteğine ilişkin görüşleri. Ankara Üniversitesi Ĕ̆itim Fakültesi Dergisi, 44(1), 1749.

Boz, Y. ve Boz, N. (2008). Kimya ve matematik öğretmen adaylarının öğretmen olma nedenleri. Kastamonu Ĕ̆itim Dergisi, 16(1), 137-144.

Bozdoğan, A., Aydın, D. ve Yıldırım, K. (2007). Öğretmen adaylarının öğretmenlik mesleğine ilişkin tutumları. Ahi Evran Üniversitesi Kırşehir Eğitim Fakültesi Dergisi, 8(2), 83-97.

Brookhart, S.M. ve Freeman, D.J. (1992). Characteristics of entering teacher candidates. Review of Educational Research, 62(1), 37-60.

Bruinsma, M. ve Jansen E.P.W.A. (2010). Is the motivation to become a teacher related to pre-service teachers' intentions to remain in the profession? European Journal of Teacher Education, 33(2), 185200.

Buldur, S. ve Bursal, M. (2015). Fen bilgisi öğretmen adaylarının meslek tercih nedenlerinin etki düzeyleri ve mesleki geleceklerine yönelik beklentileri. Necatibey Eğitim Fakültesi Elektronik Fen ve Matematik Eğitimi Dergisi (NEF-EFMED), 9(1), 81-107.

Bursal, M. ve Buldur, S. (2013). Fen bilgisi öğretmen adayları için öğretmenlik tercih nedenlerini derecelendirme ve geleceğe yönelik beklentiler ölçekleri geliştirme çalışması. Turkish Journal of Teacher Education, 2(1), 47-64. 
Bursal, M. ve Buldur, S. (2016). İlköğretim öğretmen adaylarının meslek tercih nedenleri ve geleceklerine yönelik beklentileri karşılaştırmalı bir analiz. Abant İzzet Baysal Üniversitesi Ĕ̆itim Fakültesi Dergisi, 16(2), 351-376.

Büyüköztürk, Ş., Kılıç-Çakmak, E., Akgün, Ö.E., Karadeniz, Ş. ve Demirel, F. (2008). Bilimsel araştırma yöntemleri. Ankara: Pegem Akademi.

Carnes, G. ve Albrecht, N. (2007). Academic and social-emotional effects of full-day kindergarten: The benefits of time. Emporia State Research Studies, 43(2), 64-72.

Çakıroğlu, E. ve Çakıroğlu, J. (2003). Reflections on teachereducation in Turkey. European Journal of Teacher Education, 26, 253-264.

Çelikten, M., Şanal, M. ve Yeni, Y.(2005). Öğretmenlik mesleği ve özellikleri. Erciyes Üniversitesi Sosyal Bilimler Enstitüsü Dergisi, 19(2), 207-237.

Çetin, B. (2012). İlköğretim öğretmen adaylarının profillerinin çeşitli değişkenler açısından incelenmesi. Ilköğretim Online, 11(3), 596-610.

Çevik, O. ve Yiğit, S. (2009). Eğitim fakültesi öğrencilerinin profillerinin belirlenmesi: Amasya Üniversitesi örneği. Cumhuriyet Üniversitesi Sosyal Bilimler Dergisi, 33(1), 89-106.

Downing, J.E., Ryndak, D.L. ve Clark, D. (2000). Paraeducators in inclusive classrooms: Their own perceptions. Remedial and Special education, 21(3), 171-181.

Ekiz, D. (2006). Sınıf öğretmenliği mesleğine yönelen adayların profilleri ve geleceğe yönelik beklentilerinin incelenmesi. Furat Üniversitesi Sosyal Bilimler Dergisi, 16(1), 131-147.

Erdiller-Yatmaz, Z.B., Erdemir, E. ve Erbil, F. (2019). Okul öncesi öğretmen adaylarının bakış açısından: Neden öğretmenliği seçtiler ve nasıl çocuk/çocukluk algıları var. Journal of Theoretical Educational Science, 12(1), 316-341.

Eret-Orhan, E. ve Ok, A. (2014). Öğretmenlik programlarını kimler tercih ediyor? Adayların giriş özellikleri ve öğretmenliğe yönelik tutumları. Hacettepe Üniversitesi Ĕ̆itim Fakültesi Dergisi, 29(4), 75-92.

Eskicumalı, A. (2002). Okul bilgisinin dağıtılması ve eğitimde gruplama. Kuram ve Uygulamada Eğitim Yönetimi, 29, 47-68.

Hacıömeroğlu, G. ve Şahin-Taşkın, Ç. (2009, Mayıs). Öğretmen adaylarının öğretmenlik mesleğini tercih sebepleri. 1. Uluslararası Türkiye Eğitim Araştırmaları Kongresi'nde sunulmuş bildiri, Çanakkale Onsekiz Mart Üniversitesi, Çanakkale.

Haktanır, G., Dağlığlu, H.E. ve Güler, T. (2010). Türkiye'de okul öncesi eğitimin mevcut durumu. UNESCO Araştırma Raporu, Ankara.

Kılcan, B., Keçe, M., Çepni, O. ve Kılınç, Ç. (2014). Prospective teachers' reasons for choosing teaching as a profession. Kastamonu Ĕ̆itim Dergisi, 22(1), 69-80.

Kuruüzüm, A. ve Çelik, N. (2005). İkinci mertebe faktör modeli ile öğretmen iş doyumunu belirleyen faktörlerin analizi. Hacettepe Üniversitesi Eğitim Fakültesi Dergisi, 29, 137-146.

Mtika, P. ve Gates, P. (2011). What do secondary trainee teachers say about teaching as a profession of their "choice" in Malawi?. Teaching and Teacher Education, 27, 424-433. 
Nalçacı, A. ve Sökmen, Y. (2016). Öğretmen adaylarının mesleği tercih nedenleri ve öğretmenlik mesleğine yönelik tutumları arasındaki ilişki. Journal of Kirsehir Education Faculty, 17(3),717-727.

Ok, A. ve Önkol, P. (2007). Öğretmen yetiştirme programlarındaki öğretmen adaylarının profili. Eğitim ve Bilim, 32(143), 13-26.

Özbek, R., Kahyaoğlu, M. ve Özgen, N. (2007). Öğretmen adaylarının öğretmenlik mesleğine yönelik görüşlerinin değerlendirilmesi. Sosyal Bilimler Dergisi, 9(2), 221-232.

Özsoy, G., Özsoy, S., Özkara, Y. ve Memiş, A.D. (2010). Öğretmen adaylarının öğretmenlik mesleğini tercih etmelerinde etkili olan faktörler. Ilköğretim Online, 9(3), 910-921.

Öztürk-Akar, E. (2012). Motivations of Turkish pre-service teachers to choose teaching as a career. Australian Journal of TeacherEducation, 37(10), 67-84.

Richardson, P.W. ve Watt, H.M.G. (2005) 'I've decided to become a teacher': Influences on career change. Teaching and Teacher Education, 21(5), 475-489.

Rots, I., Aelterman, A., Devos, G. ve Vlerick, P. (2010). Teacher education and the choice to enter the teaching profession: A prospective study. Teaching and TeacherEducation, 26,1619-1629.

Saban, A. (2003). A Turkish profile of prospective elementary school teachers and their views of teaching. Teaching and Teacher Education, 19, 829-846.

Sak, R. ve Tezel-Şahin, F. (2007, Eylül). Erkek okul öncesi öğretmenlerine genel bir bakış. XVI. Ulusal Eğitim Bilimleri Kongresi'nde sunulmuş bildiri. Gaziosmanpaşa Üniversitesi Eğitim Fakültesi, Tokat.

Santoro, E.A. (2011). Full-day kindergarten: A case study on the perceptions of district leaders in four suburban Pennsylvania school districts. Doktora Tezi. Temple University, USA.

Sinclair, C. (2008) Initial and changing student teacher motivation and commitment to teaching. Asia Pacific Journal of TeacherEducation, 36(2), 79-104.

Şahin, İ. (2011). Öğretmen adaylarının öğretmen istihdamı ve mesleki geleceklerine ilişkin görüşleri. Kuram ve Uygulamada Eğitim Bilimleri, 11(3), 1167-1184.

Telef, B.B. (2011). Öğretmenlerin öz-yeterlikleri, is doyumları, yasam doyumları ve tükenmişliklerinin incelenmesi. İlköğretim Online, 10(1), 91-108.

Thomson, M.M., Turner, J.E. ve Nietfeld, J.L. (2011). A typological approach to investigate the teaching career decision: Motivations and beliefs about teaching of prospective teacher candidates. Teaching and Teacher Education, 28(3), 324-335.

Tomšik, R. (2016). Choosing teaching as a career: Importance of the type of motivation in career choices. TEM Journal, 5(3), 396-400.

Watt, H.M.G. ve Richardson, P.W. (2008). Motivations, perceptions, and aspirations concerning teaching as a career for different types of beginning teachers. Learning and Instruction, 18, 408428.

Yalçın, F.A., Yalçın, M. ve Macun, B. (2017). Okul öncesi öğretmenlerinin okul öncesi eğitimde öğretmen cinsiyeti ile ilgili görüşleri. Bayburt Ĕ̆gitim Fakültesi Dergisi, 12(24), 693-710.

Yazıcı, H. (2009). Ögretmenlik meslegi, motivasyon kaynakları ve temel tutumlar: Kuramsal bir bakış. Kastamonu Ĕ̆itim Dergisi, 17(1), 33-46. 
Yıldırım, A. ve Şimsek, H. (2013). Sosyal bilimlerde nitel araştırma yöntemleri. Ankara: Seçkin.

Yu, Y. ve Bieger, G. (2013). Motivations for choosing a teaching career and deciding whether or not to teach in urban settings. Journal of the EuropeanTeacherEducation Network, 8, 62-90.

\section{Yazarların Katkı Oranı Beyanı}

Yazarlar çalışmaya eşit oranda katkı sağlamıştır.

\section{Destek ve Teșekkür Beyanı}

Bu araştırmada herhangi bir kurum, kuruluş ya da kişiden destek alınmamıştır.

\section{Çatışma Beyanı}

Araştırma ile ilgili diğer kişi ve kurumlarla herhangi bir kişisel ve finansal çıar çatışması yoktur.

\section{Etik Bildirim}

$\mathrm{Bu}$ araştırma, 01.01.2020 tarihinden önce yapıldığından etik kurul kararı zorunluluğu yoktur. Yapılan bu araştırmada bilimsel, etik ve alıntı kurallarına uyulmuştur. 